https://www.sworldjournal.com/index.php/swj/article/view/swj08-05-085 DOI: 10.30888/2663-5712.2021-08-05-085

\title{
UDK 821.111
}

\section{RESEARCH ON SMART EDUCATION ДОСЛІДЖЕННЯ СМАРТ-ОСВІТИ}

Chaikovska O.V./ Чайковська O.B. PhD in Philological Sciences, Associate Professor/ кандидат філологічних наук, дочент ORCID 0000-0001-9161-4574 State Agrarian and Engineering University in Podilya Kamianets-Podilskyi, Shevchenko, 13, 32316 Подільський державний аграрно-технічний університет Кам'янець-Подільський, вул. Шевченка, 13, 32316

Abstract. The present paper aims at determining the main characteristics of smart education. Literature review showed that smart education is an effective, self-directed, motivated, adaptive, resource-enriched, and technology-embedded type of learning. The devices, platforms and apps that make smart education possible are examined in the paper. It has been found that the main challenges for educational establishments deal with the quality of teachers' digital competencies, skills and designing smart course-book.

Keywords: smart education, devices, platforms, challenges, technology

\section{Introduction}

Internet, social media, MOOCs (Massive open online courses among which the most popular are Coursera, MIT Opencourseware, EDX, Udacity and My education path, artificial intelligence, open educational resources are becoming an integral part of the educational and living space. [12, p.187]. Education reflects the main changes and new trends in the economic and social spheres. As soon as computers rapidly gained popularity among people all over the world e-learning based on using computers, multimedia technology was gradually implemented in educational establishments to acquire knowledge and develop skills. The gap between the traditional content of teaching materials, learning methods and opportunities of computer-based learning caused the development of a blended learning concept that provided a gradual transition from traditional learning to computer-based one since blended learning combines traditional in-class activities and e-learning. The concept of mobile learning (m-learning) appeared parallel to smartphone evolution. Mlearning began to develop into a powerful education trend - u-learning (ubiquitous learning).

\section{Research results}

Covid restrictions fastened the digitalization of all spheres of human lives and education is not an exception. We can't deny the fact that audio presentations, movie fragments, slides, the transmission of educational TV programs, video clips, and teleconferences are not trendy anymore. The focus should be done on the Internet that stores organized learning content, communication programs and platforms, learning management systems that facilitate access to learning materials. We realize that free access to the information causes not only advantages but determines the necessity of acquiring media literacy skills with the teachers and students. To our point of view, participating in online courses, webinars, seminars can help not only to develop the skills of navigation in the "network" but also teach students to critically evaluate information and select valuable and effective materials. 
Recently the term "smart education" gained popularity and became a new trend in $21^{\text {st }}$-century education. Smart education is determined as "a student-centric, digital, collaborative approach to education that prepares the next generation to participate in the digital economy" [7]. Academics highlight such characteristics of "smart education" as flexibility and define "smart education" as a flexible type of learning in an interactive educational environment with the help of content from world resources available in free access $[9,13]$. The flexibility, to Semenikhina O. V. point of view, assumes the presence of a large number of sources, the maximum variety of multimedia (audio, video, graphics), the ability to quickly and easily adjust to the level and needs of the listener. Tikhomirov V.P. interprets the abbreviation SMART as follows: S (Self Directed) - providing opportunities for self-determination of what to study and effective organization of self-study); M (Motived) - motivation of active cognitive activity; A (Adaptive) - adapting the methods, place and time of study for a specific subject who wants to purchase educational services; R (Resource Free) ensuring free access to educational resources; $\mathrm{T}$ (Technology Embedded) permanent provision of the learning process with modern technologies. In addition, a researcher states that Smart education is an association of educational institutions and faculty to carry out joint educational activities on the Internet-based on common standards, agreements and technologies. It is about sharing and using content, about co-education [13].

Overseas researchers determined the crucial components of smart learning, and they are context-aware ubiquitous learning $[3,6,7]$, learner-centric or individualized [13] or and service-oriented characteristics [4]. They describe smart learning as effective, tailored learning, self-directed, motivated, adaptive, resource-enriched, and technology-embedded [MEST, 2011]. Through analyzing the smart education projects, carried out in Malaysia, Singapore, Australia, South Korea, Finland, UAE, $\mathrm{Zhu}$, et al. could conclude that the goal of smart education is to foster a workforce that masters 21 st-century knowledge and skills to meet the need and challenges of society [8, p.5]. According to Zhu, et al. [11], "the objective of smart education is to improve learners' quality of lifelong learning" $[8, \mathrm{p} .6]$.

However, various challenges hinder education establishments from realizing the full potential of smart education. As soon as the smart education model involves teacher and learner presence and technology, the basic challenges consider, primarily, the teaching qualification and competencies, the ability and motivation for life-long learning. Smart teaching provides the creation of such learning conditions and strategies when students don't get ready knowledge and instructions for acquiring practical skills but prepare them for gaining their own experience and developing skills. Smart teacher in smart education is a "qualified content navigator" [11], participant of the educational process, which constantly uses technological innovations and the Internet to achieve a new quality of professional training that meets the requirements of Smart society [10]. The second important issue concerning smart education is designing smart course books since traditional textbooks can't motivate the students. Learning courses should include quality content, multimedia and inner internet resources, interactive collaboration tools, testing instruments.

The most common devices used in smart education are tablets, smartphones with 
special smart apps, smart boards. The software developers are constantly improving their apps to help the teacher make the class activities more efficient and motivated. Google can also offer a wide variety of tools and resources for learning. For example, Google Classroom is used to organize the classes remotely, make tests and control students' performance. Google play market provides a lot of smart apps to make learning both easier and more enhancing. During our foreign language classes we Quizlet as an alternative to paper-based dictionaries, exercises and tests; Podstation [1] and Audacity [2] to work with authentic texts and design own podcasts. Zoom, Viber, Seesaw, Teach Learn Lead, Kahoot, Remind may be also used as an alternative to Google.

Smart education will require the development of online communities, social networks, where teachers will be able to share educational content. Social media platforms Facebook, Instagram and Twitter, video hosting Youtube make such interaction possible with the students and teachers around the world. These social media platforms gained their popularity not only due to free access to communicative space but also the possibility to create virtual classes.

Learner presence in smart education is characterized by autonomous and collaborative learning and efficient technology use. Digital technologies should be incorporated in learning and development. First of all, technology provides the connection between teachers and a learner, ever-present access to learning, encourages personalized learning and each student may choose his learning styles and strategies. Interactive equipment such as Smart Boards and Sympodium display is a presentation created simultaneously with the presenter speaks. The educational material, written notes and comments on smartboards can be transmitted to students, stored on magnetic media, printed or sent by e-mail to the students.

\section{Conclusions}

Smart education is being gradually implemented in schools and universities. But the provision of educational establishments with smart devices is not enough to develop smart learning. The focus should be done on the computer skills of the teacher and the ability to design and plan classes with the implementation of smart devices. Smart education will ensure the transmission from passive content to active, interactive, online, will create conditions of synchronized delivery of knowledge, which will provide a quality of education that will satisfy students.

\section{References:}

1. Chaikovska O. Podcasts in teaching ESL. Scientific Herald of the Institute of Vocational Education and Training of the National Academy of Pedagogical Sciences, 2018. - Вип.16, С. 142-146. DOI: https://doi.org//10.32835/22235752.2018.16.142-146

2. Chaikovska O. Вплив подкастів, створених за допомогою AUDACITY, на вдосконалення граматичних навичок. Електронне наукове фахове видання “Відкрите освітне Е-середовище сучасного університету", 2020. - Вип. 8, С. 1-7. DOI: https://doi.org/10.28925/2414-0325.2020.8.1

3. Hwang. Definition, framework and research issues of smart learning environments-a context-aware ubiquitous learning perspective. Hwang // Smart 
Learning Environments, 2014. - Вип. 1(1), С. 1-14.

4. Kim J.Y., Cho B.G., Lee. Evolution to smart learning in public education: a case study of Korean public education, in Open and Social Technologies for Networked Learning, ed. by L. Tobias, R. Mikko, L. Mart, T. Arthur (Berlin Heidelberg, Springer, 2013), pp.170-178

5. MEST: Ministry of Education, Science and Technology of the Republic of Korea, Smart education promotion strategy, President's Council on National ICT Strategies (2011)

6. Scott R., Benlamri. Context-aware services for smart learning spaces. Learning Technologies, IEEE Transactions, 2010. - Вип. 3(3), С.214-227.

7. Shoikova E., Nikolov R., Kovatcheva E. Conceptualising of Smart Education. Scientific journal "Electrotechnika and Electronica" (E+E), 2017. - Вип. 3-4, p. 2937.

8. Zhu ZT., Yu MH., Riezebos, P. A. The research framework of smart education. Smart Learn. Environ, 2016. - Вип. 3(4). https://doi.org/10.1186/s40561016-0026-2

9. Герасименко Т.Л. Smart-технологии (вебинар и социальные сети) в преподавании иностранного языка в неязыковом вузе / Т.Л. Герасименко, И.В. Грубин, Т.М. Гулая, О.Н. Жидкова, С.А. Романова // Экономика, статистика и информатика. Вестник УМО. - М.: Изд-во ФГБОУ ВО «РЭУ им. Г.В. Плеханова», 2012. - № 5. - С. 9 - 12.

10. Молчанов А.С. Смарт-университет как клиенто-ориентированная модель университета. URL: htttps//www.slideshare.net/alexmolchanow/ss35120636 (дата звернення: 05.10.2019)

11. Семеніхіна О. В. Нові парадигми у сфері освіти в умовах переходу до SMART- суспільства // Вісник Сумського державного педагогічного університету ім. А. С. Макаренка, 2015 - №5. - С. 34-44

12. Степаненко E., Zelikovska O. Smart-технологии в преподавании иностранного языка в профессиональной сфере, 2017. - №5. С. 186-193.

13. Тихомиров В.П. Smart Education: новый подход к развитию образования [Электронный ресурс] // В. П. Тихомиров, Н. В. Тихомирова. Режим доступа: http://www.elearningpro.ru/forum/topics/Smart Education.

Анотація. Дана стаття спрямована на визначення основних характеристик smart освіти. Аналіз літератури дає нам право говорити про те, щуо smart освіта є ефективною, мотивованою, адаптивною, збагаченою ресурсами та сучасними навчальними технологіями. Комп'ютери, смартфони, платформи та додатки, які роблять розумну освіту можливою, розглядаються у роботі. Встановлено, що основними викликами для навчальних закладів $\epsilon$ якість циифрових компетенцій вчителів, навички та розробка смарт-підручників.

Ключові слова: розумна освіта, пристрої, платформи, виклики, технологї 